Filol. Linguíst. Port., São Paulo, v. 17, n. 1, p. 9-10, jan./jun. 2015 http://dx.doi.org/10.11606/issn.2176-9419.v17i1p9-10

\title{
O GT Linguística do Texto e Análise da Conversação
}

O GT Linguística do Texto e Análise da Conversação (GT LTAC) da Associação Nacional de Pós-graduação em Letras e Linguística (ANPOLL), no biênio 20122014, lançou um projeto editorial perspectivando a socializaçáo de trabalhos de seus membros. Nessa direção, pesquisadores da Análise da Conversação, sob a coordenação dos professores Leonor Lopes Fávero (USP e PUC/SP), Luiz Antônio da Silva (USP) e Marise Adriana Mamede Galvão (UFRN), engajaram-se no projeto e estão concretizando a proposta, nesta edição da Revista de Filologia e Linguística Portuguesa.

Agradecemos, assim, aos colegas que aderiram ao projeto editorial, uma vez que, muito mais que responder afirmativamente a uma proposta, estấo presenteando a comunidade científica interessada por questóes linguísticas da/na modalidade falada da língua.

O projeto iniciado em outubro de 2013 , na reunião intermediária do GT, realizada na Universidade Cruzeiro do Sul, por ocasião do $5^{\circ}$. Seminário Internacional de Linguística, foi prorrogado até 2016, quando fomos reconduzidos à coordenação do GT, no $29^{\circ}$. Encontro Nacional da ANPOLL, realizado na Universidade Federal de Santa Catarina, de 09 a 11 de junho de 2014.

É, pois, uma honra cumprimentar os organizadores, que também são autores: Profa. Dra. Leonor Lopes Fávero, Prof. Dr. Luiz Antônio Silva e Profa. Dra. Marise Adriana Mamede Galvão, assim como os demais autores dos artigos: Prof. Dr. José Gaston Hilgert, Profa. Dra. Kazue Saito Monteiro de Barros, Profa. Dra. Maria Lúcia C. V. Oliveira Andrade, Profa. Dra. Ana Rosa Ferreira Dias, Prof. Dr. Gil Roberto Costa Negreiros, Profa. Dra. Maria Flávia Figueiredo, Profa. Dra. Maria Francisca Oliveira Santos, Profa. Dra. Zilda Gaspar Oliveira de Aquino e Profa. Dra. Josilete Alves Moreira de Azevedo e o Prof. Dr. Antonio Briz Gómez, convidado estrangeiro. Todos eles se debruçaram sobre uma questão basilar para o sucesso do processo de ensino e de aprendizagem da língua portuguesa: a oralidade. Apesar da ampla divulgação e de recomendaçóes oficiais, muitos professores do ensino básico ainda desconhecem o contínuo entre fala e escrita; em decorrência, consideram as marcas de fala no texto escrito como erro. 
Os leitores terão o acesso a um conjunto de gêneros discursivos / textuais em que fenômenos da fala são analisados à luz de um quadro teórico que permitiu discussão de temas decisivos para o êxito do ensino de língua portuguesa, em se que reconhece a relevância da modalidade falada, situada em um contínuo em relação à escrita. Nessa direção, ressaltamos que os autores focalizam, por exemplo, a enunciação, a interação, a cortesia, a retextualização, efeitos da oralidade em textos literários, sequências textuais, argumentaçáo na perspectiva da nova retórica e concepções de professores sobre a relação oralidade / ensino de língua portuguesa.

Por fim, reiteramos nosso prazer, ao ver o projeto editorial do GT Linguística do Texto e Análise da Conversação, tornar-se uma realidade, contribuindo para socializaçáo dos conhecimentos gerados por pesquisadores do mais alto nível, e permitindo aos professores de língua portuguesa do ensino básico a valorização do contínuo entre fala e escrita.

Natal, 13 de julho de 2015.

Profa. Dra. Maria das Graças Soares Rodrigues

Prof. Dr. João Gomes da Silva Neto Coordenadores do GT Linguística do Texto e Análise da Conversação da ANPOLL 